\title{
Analysis of the SARS-CoV-2 Outbreak in Northern Cyprus using a Mathematical Model
}

\author{
Tamer Sanlidag \\ Near East University \\ Nazife Sultanoglu ( $\nabla$ nazife.sultanoglu@neu.edu.tr) \\ Near East University \\ Bilgen Kaymakamzade \\ Near East University \\ Evren Hincal \\ Near East University \\ Murat Sayan \\ Near East University \\ Kaya Suer \\ Near East University \\ Buket Baddal \\ Near East University
}

\section{Research Article}

Keywords: SARS-CoV-2, Northern Cyprus, epidemics, mathematical model

Posted Date: May 13th, 2020

DOI: https://doi.org/10.21203/rs.3.rs-28704/v1

License: (c) (1) This work is licensed under a Creative Commons Attribution 4.0 International License.

Read Full License 


\section{Analysis of the SARS-CoV-2 Outbreak in Northern Cyprus using a}

\section{Mathematical Model}

Tamer Sanlidag ${ }^{1,2}$, Nazife Sultanoglu ${ }^{1,3^{*}}$, Bilgen Kaymakamzade ${ }^{1,4}$, Evren Hincal ${ }^{1,4}$, Murat Sayan ${ }^{1,5}$, Kaya Suer ${ }^{6}$, Buket Baddal ${ }^{1,3}$

${ }^{1}$ DESAM Institute, Near East University, Nicosia, Cyprus

${ }^{2}$ Department of Medical Microbiology, Faculty of Medicine, Celal Bayar University, Manisa, Turkey

${ }^{3}$ Department of Medical Microbiology and Clinical Microbiology, Faculty of Medicine, Near East University, Nicosia, Cyprus

${ }^{4}$ Near East University, Department of Mathematics, Nicosia, Cyprus

${ }^{5}$ Kocaeli University, Faculty of Medicine, Clinical Laboratory, PCR Unit, Kocaeli, Turkey ${ }^{6}$ Near East University, Faculty of Medicine, Department of Infectious Diseases and Clinical Microbiology, Nicosia, Cyprus

*Corresponding author:

Phone number: +90 $3926802000-3056$

E-mail address: nazife.sultanoglu@neu.edu.tr

Declarations

There are no conflicts of interest to disclose. 


\section{Abstract}

The present study studied the dynamics of SARS-CoV-2 in Northern-Cyprus (NC) by using real data and a designed mathematical model. The model consisted of two equilibrium points, which were disease-free and epidemic. The stability of the equilibrium points was determined by the magnitude of the basic reproduction number $\left(\boldsymbol{R}_{\mathbf{0}}\right)$. If $\boldsymbol{R}_{\mathbf{0}}<\mathbf{1}$, the disease eventually disappears, if $\boldsymbol{R}_{\mathbf{0}} \geq \mathbf{1}$, the presence of an epidemic is stated. $\boldsymbol{R}_{\mathbf{0}}$ has been calculated patient zero, with a range of 2.38 to 0.65 . Currently, the $\boldsymbol{R}_{\mathbf{0}}$ for NC was found to be 0.65 , indicating that NC is free from the SARS-CoV-2 epidemic.

Keywords: SARS-CoV-2, Northern Cyprus, epidemics, mathematical model

\section{Introduction}

Coronaviruses are from the subfamily of Orthocoronavirinae that belongs to the Coronaviridae family and predominantly lead to respiratory and gastrointestinal tract infections. Thus far in the $21^{\text {st }}$ century, 3 outbreaks have been associated with zoonotic coronaviruses that have gained the capacity for human-to-human transmission leading to global health concerns [1]. These are severe acute respiratory syndrome coronavirus (SARS-CoV), Middle East respiratory syndrome coronavirus (MERS-CoV) and the recently identified "2019 novel coronavirus", which has subsequently been given the name severe acute respiratory syndrome coronavirus 2 (SARS-CoV-2) [1], [2]. The SARSCoV-2 outbreak still continues around the world and causes Coronavirus Disease 2019 (COVID-2019), with clinical manifestations primarily including dry cough, high fever and shortness of breath and an overall mortality rate of $2.6 \%$ [3]. The SARS-CoV-2 was first identified in the city of Wuhan in Hubei Province, China in late 2019. The outbreak has since spread all over the world from China and caused a pandemic, which was officially declared by the World Health Organization (WHO) on $11^{\text {th }}$ March 
2020 [4]. According to the $1^{\text {st }}$ May 2020 WHO COVID-19 Situation Report, 3175207 confirmed cases and 224172 deaths have occurred globally. Although the spread of the disease started in China, the country has successfully managed to control the SARS-CoV-2 outbreak with a decreasing trend of new cases. In total, there have been 84385 confirmed cases and 4643 deaths in China. However, the number of SARS-CoV-2 cases is showing an increasing trend in other countries around the world. In the Eastern Mediterranean Region, a total of 188585 confirmed cases and 7598 deaths have been confirmed [5]

Cyprus is the third largest island located in the Mediterranean region. In the North side of Cyprus, the population is approximately 374299 , and largely consists of Turkish Cypriots [6]. In Northern Cyprus, the SARC-CoV-2 outbreak started with patient zero on $9^{\text {th }}$ March 2020 [7]-[12]. Patient zero was a female German tourist who arrived in Northern Cyprus on $8^{\text {th }}$ March 2020 and was diagnosed as SARS-CoV-2 positive on $9^{\text {th }}$ March 2020 after showing symptoms of a high fever, while the first Northern Cyprus citizen diagnosed with SARS-CoV-2 had a history of travel to England. This suggested that SARS-CoV-2 entered Northern Cyprus through the routes of Germany and England [13], [14].

Currently, a total of 1257 tests have been conducted resulting in 108 SARS-CoV-2 positive cases in Northern Cyprus, where 31 were German citizens and 77 from Northern Cyprus, of whom 3 are still receiving treatment, 101 have recovered and 4 have died ( 2 German, 2 Northern Cyprus citizens) have occurred. Presently in Northern Cyprus the SARS-CoV-2 death rate is 3.7, recovery rate is 0.93 and the test rate is 0.31 . After the identification of SARC-CoV-2 positive patient zero, strategic precautions were taken across Northern Cyprus to prevent and control further transmission of the SARS-CoV-2 outbreak. These precautions included: sea, air and land border gates were closed to citizens of all other countries, Northern Cyprus citizens entering the country were required to remain in quarantine for 14 days in places designated by the government (until now, a total of 1819 individuals have been quarantined for a period of 14 days at different times due to the risk of 
carrying the SARS-COV-2), a full curfew from $21.00 \mathrm{pm}$ to 6.00 am was announced, and within the scope of meeting basic needs, only markets and pharmacies remain open and all other entertainment places/shops are closed in the private sector, collective worship is banned, and schools and universities are closed [15], [16]. In addition to the precautions taken, informative awareness campaigns have been raised by official government social media sites and native television channels to raise public awareness with regard to the SARS-CoV-2 outbreak. Also, sanitizing of the universities, schools, houses, and streets by private sector, municipality and authorities at the beginning of the SARS-CoV-2 outbreak is believed to have had a significant impact in preventing further transmission of SAR-CoV-2. Figure 1 was generated by the team on $11^{\text {th }}$ March 2020 and presented to the government science board to take these necessary actions, which were implemented immediately.

This study aimed to calculate the current and predicted situation of the Northern Cyprus SARS-CoV-2 outbreak using real data with a designed mathematical model. The real data integrated into the mathematical model included quarantined individuals, as well as SARS-CoV-2 infected and hospitalized patients with mild to severe symptoms, which were obtained from the Health Ministry of Northern Cyprus. The designed mathematical model consisted of two equilibrium points, which were disease free and epidemic. The magnitude of the basic reproduction number $\left(\boldsymbol{R}_{\mathbf{0}}\right)$ was the determined of the stability of the two equilibrium points. If it is below $1\left(\boldsymbol{R}_{\mathbf{0}}<1\right)$, the disease free equilibrium is stable indicating the absence of a SARS-CoV-2 epidemic; however, if it is equal or above $1\left(\boldsymbol{R}_{\mathbf{0}} \geq 1\right)$, the epidemic equilibrium point is stable indicating the presence of a SARS-CoV-2 epidemic. 


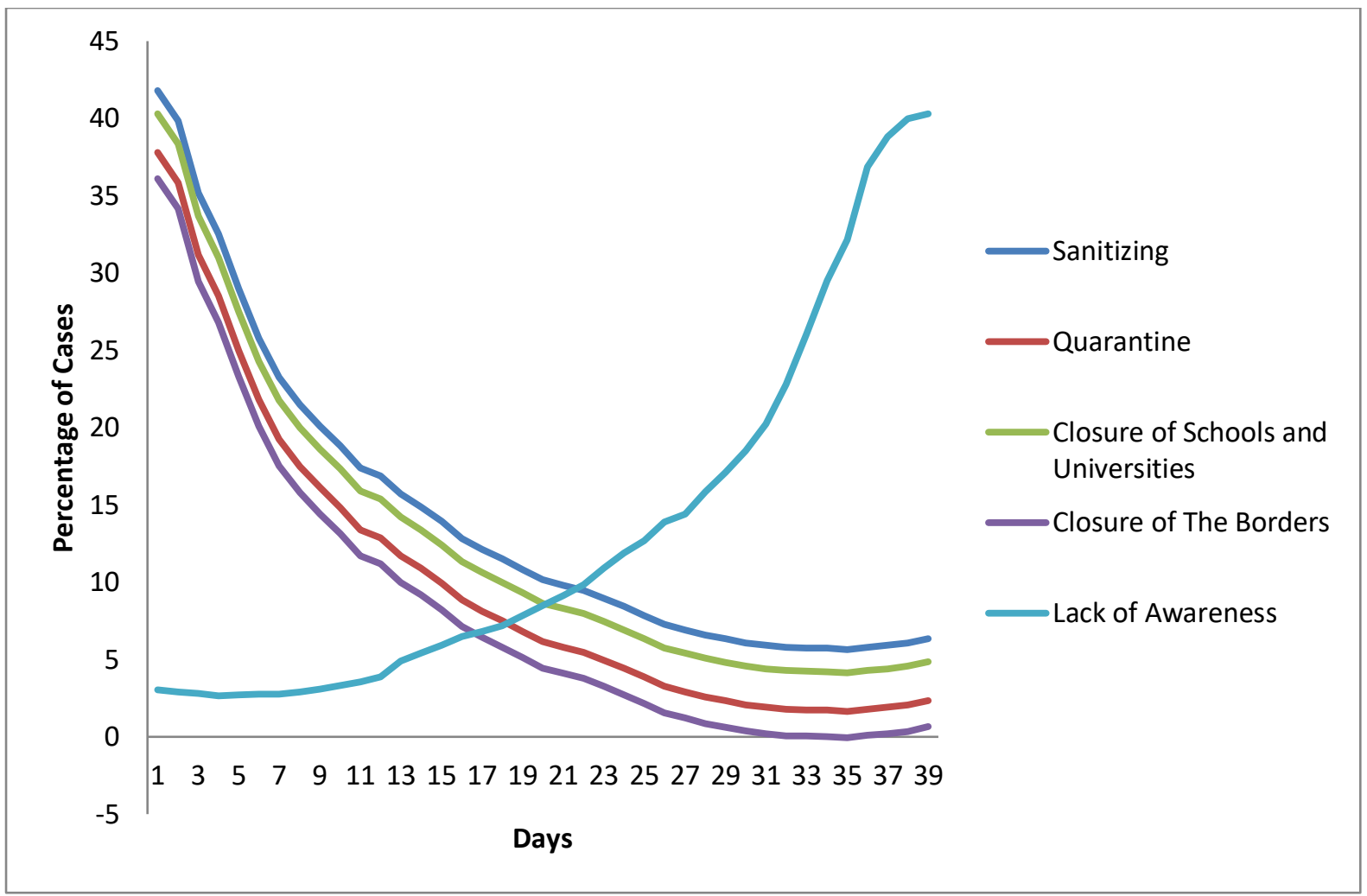

Figure 1. Most effective methods to prevent coronavirus epidemic

Sanitizing, home quarantine as well as quarantining citizens entering the country from abroad, closure of the schools and universities, and closure of the sea, air and land border gates to the country were recommended and implemented by the government soon after the identification of patient zero in Northern Cyprus in order to control the SARS-CoV-2 outbreak. Also, to prevent further transmission of the SARS-CoV-2 due to the lack of awareness, many awareness campaigns were initiated to educate people regarding how to behave in terms of preventing further transmission and protecting themselves.

\section{Method}

We adapted Northern Cyprus data to the model which was constructed by Umar et al. [17]. This model was constructed as a SEIR type model for COVID-19. The model is divided into seven compartments, which are susceptible, exposed, quarantined, SARS-CoV-2 infected and indicated 
moderate symptoms, infected and indicate severe symptoms, hospitalized, and recovered. By using the next generation matrix method, the basic reproduction number was found as follows:

$$
\begin{aligned}
& R_{0} \\
& =\beta\left(\frac{\left(\tau_{1} \theta_{1} b_{1}+\tau_{2} \theta_{1} \theta_{3}+\tau_{2} \theta_{2} a_{2}\right) b_{2} a_{3}+\tau_{3} \theta_{4} a_{3}\left(\theta_{2} a_{2}+\theta_{1} \theta_{3}\right)+\tau_{4}\left(\theta_{2} a_{2}+\theta_{1} \theta_{3}\right)\left(\omega b_{2}+\varphi \theta_{4}\right.}{a_{1} a_{2} a_{3} b_{1} b_{2}}\right)
\end{aligned}
$$

where, $a_{1}=\theta_{1}+\theta_{2}, a_{2}=\delta_{1}+\theta_{3}, a_{3}=\delta_{4}+\alpha_{3}, b_{1}=\delta_{2}+\omega+\theta_{4}+\alpha_{1}, b_{2}=\delta_{3}+\varphi+\alpha_{2}$.

The model is given as follows,

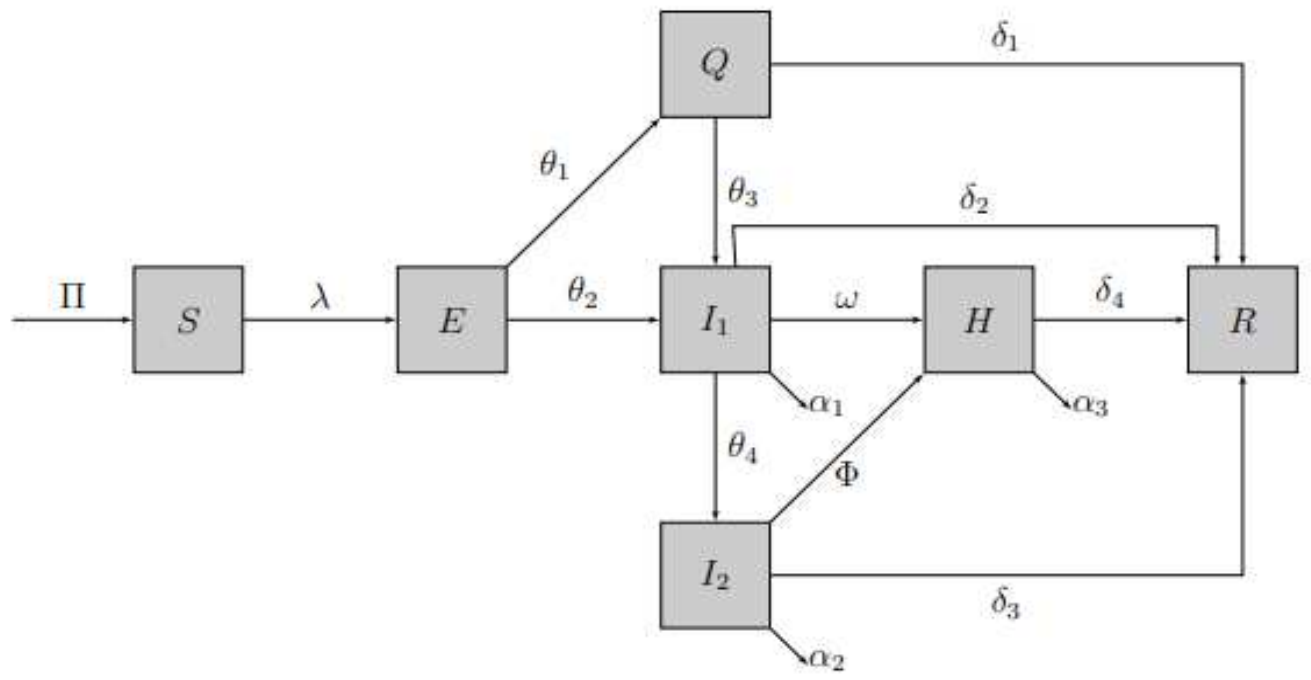

The meanings of the parameters are given in Table 1 and the values of the parameters are calculated through Statistical Package for the Social Sciences by using the Monte Carlo Simulation Method (SPSS version 24.0). 
Table 1. List of variables and parameters needed for Northern Cyprus

\begin{tabular}{|c|l|l|}
\hline Variable/Parameter & Meaning & Value \\
\hline$\beta$ & Transmission rate & 0.5432 \\
\hline$\alpha_{i},(i=1,2,3)$ & Disease induced death rates & $0.045,0.8,0.037$ \\
\hline$\theta_{i},(i=1,2,3,4)$ & Progression rates & $0.4398,0.0571,0.0075,0.0054$ \\
\hline$\omega$ & Hospitalization rate from $I_{1}$ class & 0.000089 \\
\hline$\varphi$ & Hospitalization rate from $I_{2}$ class & 0.00098 \\
\hline$\delta_{i},(i=1,2,3,4)$ & Recovery rates & $0.86,0.94,0.2,0.96$ \\
\hline$\tau_{i},(i=1,2,3,4)$ & Contact rate of each compartments & $0.16,0.45,0.46,0.056$ \\
& $I_{1}, I_{2}, Q, H$ respectively to $S$ & \\
\hline
\end{tabular}

[18], [19].

\section{Results}

From the designed mathematical model, the value of was continuously calculated based on the changing dynamics of the SARS-CoV-2 outbreak in Northern Cyprus. The $\boldsymbol{R}_{\mathbf{0}}$ value ranged between 2.38 to 0.65 in the period from $11^{\text {th }}$ March to $26^{\text {th }}$ April 2020. With the real data used in Table 1 , the current $\boldsymbol{R}_{\mathbf{0}}$ for Northern Cyprus was calculated to be 0.65 . Therefore, this indicates that Northern Cyprus is currently free from SARS-CoV-2 epidemic and the disease will eventually die out (Figure 2). Furthermore, by using Matlab software, the designed mathematical model was simulated to predict what is likely to happen in the future with regard to the SARS-CoV-2 outbreak in Northern Cyprus. The obtained results indicated a steep rise from $11^{\text {th }}$ of March to $16^{\text {th }}$ of April 2020 followed by plateau of SARS-CoV-2 infected individuals with a maximum of 133 predicted SARS-CoV-2 cases (Figure 3). 


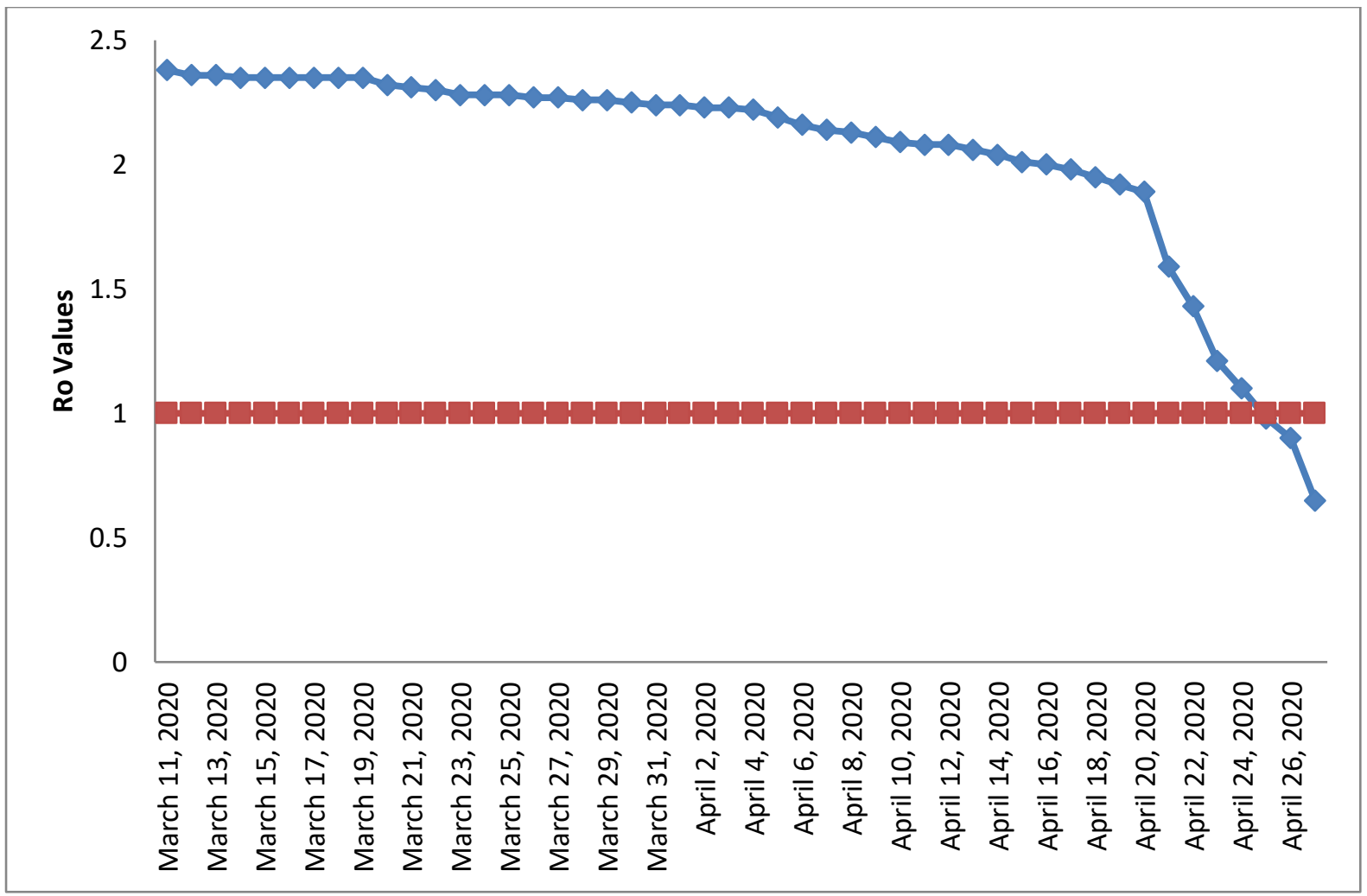

Figure 2. Northern Cyprus $\boldsymbol{R}_{0}$ pattern for SARS-CoV-2 outbreak

With the identification of the first SARS-CoV-2 positive patient, the team continuously calculated the value of $\boldsymbol{R}_{\mathbf{0}}$ with the most up-to-date daily dynamics of the outbreak in Northern Cyprus. From $11^{\text {th }}$ March to $24^{\text {th }}$ of April 2020, the SARS-CoV-2 outbreak had epidemic characteristics in Northern Cyprus since the $\boldsymbol{R}_{\mathbf{0}}$ value was above or equal to one. By $26^{\text {th }}$ of April 2020, the $\boldsymbol{R}_{0}$ value had fallen below 1, implying that the SARS-CoV-2 outbreak was not in epidemic character and the disease would start to die out. 


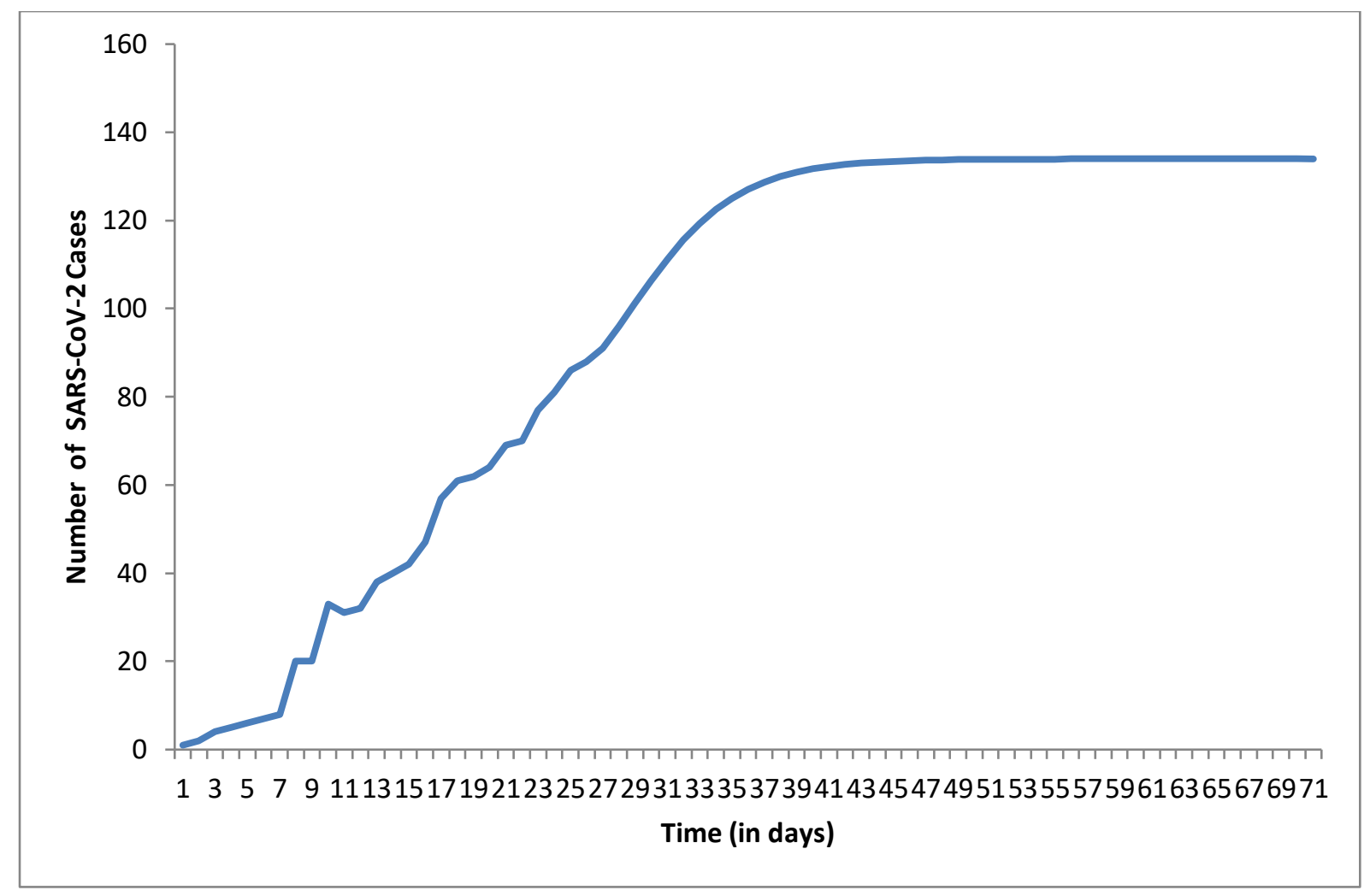

Figure 3. Northern Cyprus SEIR Model Simulation

The first SARS-CoV-2 positive patient in Northern Cyprus was identified on $9^{\text {th }}$ of March 2020. The team started to evaluate $\boldsymbol{R}_{\mathbf{0}}$ from $11^{\text {th }}$ of March 2020 , and shared the most up-todate and predicted $\boldsymbol{R}_{\mathbf{0}}$ value with the necessary authorities to implement prevention actions. Day 1 in the figure represents the $11^{\text {th }}$ of March and onwards. As can be visualized from the graph, a steep rise from day 1 to day $37\left(16^{\text {th }}\right.$ April 2020$)$ with 128 cases followed by a plateau of SARS-CoV-2 infected individuals on and after day 37 with a maximum of 133 SARS-CoV-2 cases is predicted (Day 71 is equivalent to $20^{\text {th }}$ May 2020) (Figure 3).

\section{Discussion}

The mathematical model designed by Umar et al. [18] was formulated with current real data to study the dynamics of the SARS-CoV-2 outbreak currently occurring in Northern Cyprus. The mathematical model consisted of two equilibrium points, which were disease free and epidemic. The magnitude of the $\boldsymbol{R}_{\mathbf{0}}$ number determined the stability of the equilibrium points, which was stabilized 
by the sensitivity analysis. The $\boldsymbol{R}_{\mathbf{0}}$ value is the threshold of the designed mathematical model and if the calculated value is less than one, it indicates that Northern Cyprus is currently free from the SARS-CoV-2 epidemic, but if it is greater than or equal to one, it implies that there currently is a SARS-CoV-2 epidemic in Northern Cyprus.

The parameters used in the mathematical model were obtained from Northern Cyprus Health Ministry, State Planning Organization and Northern Cyprus Presidential Crisis Center. There was a total of 108 infected SARS-CoV-2, and total of 1819 quarantined individuals from $9^{\text {th }}$ of March to $2^{\text {nd }}$ May 2020 used in this study.

The $\boldsymbol{R}_{\mathbf{0}}$ value has been evaluated since the identification of patient zero, and the latest $\boldsymbol{R}_{\mathbf{0}}$ value calculated for SARS-CoV-2 in Northern Cyprus was 0.65 , indicating that the country is currently free from SARS-CoV-2 epidemic. Furthermore, by using Matlab software, the mathematical model was simulated using the current parameters (Table 1) to predict the dynamics of the SARS-CoV-2 outbreak in Northern Cyprus in the future. This indicated that there will be a rise in the number of SARS-CoV-2 infected individuals from $11^{\text {st }}$ of March (day 1 ) to $16^{\text {th }}$ April (day 37) 2020 followed by a plateau with a maximum of 133 predicted SARS-CoV-2 cases (Figure 3).

The quarantined individuals' parameter had the greatest influence on the outcome of the $\boldsymbol{R}_{\mathbf{0}}$ and the future prediction of the dynamic of SARS-CoV-2 in the designed mathematical model. Until now, a total 1819 individuals have been quarantined in the places designated by the government as they had a high risk of carrying the SARS-CoV-2. At that time, with this high number of quarantined individuals, the $\boldsymbol{R}_{\mathbf{0}}$ value indicated the presence of an epidemic in Northern Cyprus. It was predicted since then that if the number of quarantined individuals falls below 150, and the number of SARSCoV-2 positive hospitalized patients falls below 15 , the $\boldsymbol{R}_{\mathbf{0}}$ will also fall below 1 , implying that the disease will eventually die out. From the $26^{\text {th }}$ April 2020 , the $\boldsymbol{R}_{\mathbf{0}}$ value started to fall below 1 , indicating that the SARS-CoV-2 outbreak in Northern Cyprus is not in the epidemic character, and the disease will start to disappear over time. This was due to the low number of quarantined individuals 
(20 individuals by $3^{\text {rd }}$ May 2020) and there are now only 3 hospitalized patients receiving treatment. Mathematical modelling is a rapid and reliable method that can be implemented for the study of current and future dynamics of the SARS-CoV-2 outbreak in any country. This method has been widely used for the SARS-CoV-2 outbreak by others as well [5] .

In conclusion, according to the currently available data, Northern Cyprus is free from the SARS-CoV-2 epidemic and the disease will eventually disappear with time. As a result of the measures and precautions taken, the number of SARS-CoV-2 infected individuals in Northern Cyprus is predicted to plateau on after $16^{\text {th }}$ of April with 128 SARS-CoV-2 cases, represented as day 37 in Figure 3.

This suggests that Northern Cyprus is a good model for other countries facing the outbreak due to the precaution and control measures taken rapidly as soon as the patient zero was identified. The value of the $\boldsymbol{R}_{\mathbf{0}}$ is constantly changing as new SARS-CoV-2 cases are detected. The current situation and future prediction of SARS-CoV-2 outbreak in Northern Cyprus are continually being shared by the team for the necessary authorities to take in front actions. Moreover, numerous awareness campaigns have been implemented throughout the country to increase the awareness of the SARSCoV-2 outbreak in order to instruct each Northern Cyprus citizen regarding how they should act in order to prevent further transmission of the disease. Without doubt, the awareness of the citizens and the measures taken play significant roles in controlling further transmission of the disease.

\section{References:}

[1] M. Xie and Q. Chen, "Insight into 2019 novel coronavirus - an updated intrim review and lessons from SARS-CoV and MERS-CoV," Int. J. Infect. Dis., Apr. 2020.

[2] WHO, "Naming the coronavirus disease (COVID-19) and the virus that causes it," 2020.

[Online]. Available: https://www.who.int/emergencies/diseases/novel-coronavirus2019/technical-guidance/naming-the-coronavirus-disease-(covid-2019)-and-the-virus-thatcauses-it. [Accessed: 15-Apr-2020]. 
[3] Y. Yang et al., "The deadly coronaviruses: The 2003 SARS pandemic and the 2020 novel coronavirus epidemic in China," Journal of Autoimmunity, vol. 109. Academic Press, p. 102434, 01-May-2020.

[4] WHO, "WHO Director - General's opening remarks at the media briefing on COVID-19 - 11 March 2020," 2020. [Online]. Available: https://www.who.int/dg/speeches/detail/whodirector-general-s-opening-remarks-at-the-media-briefing-on-covid-19---11-march-2020. [Accessed: 31-Mar-2020].

[5] WHO, "Coronavirus disease (COVID-19) Situation in numbers (by WHO Region)," 2020.

[6] Turkish Republic of Northern Cyprus Ministry of Health, "'It is important that our people protect themselves and take individual measures without panicking during this process,'" 2020. [Online]. Available:

https://saglik.gov.ct.tr/Haberler/DUYURULAR/ArtMID/32470/ArticleID/123665/“Halkımızınbu-s252re231te-panik-yapmadan-kendini-koruması-ve-bireysel-olarak-alması-gereken246nlemler-246nem-taşımaktadır." [Accessed: 04-Apr-2020].

[7] Turkish Republic of Northern Cyprus Ministry of Health, "'The general health of the German patient is good, her treatment continues and is under follow-up,'” 2020. [Online]. Available: https://saglik.gov.ct.tr/Haberler/DUYURULAR/ArtMID/32470/ArticleID/123702/“Almanhastanın-genel-sağlık-durumu-iyi-olup-tedavisi-devam-etmektedir-ve-takip-altındadır." [Accessed: 04-Apr-2020].

[8] Turkish Republic of Northern Cyprus Ministry of Health, "IMPORTANT EXPLANATION OF THE MINISTRY OF HEALTH," 2020. [Online]. Available:

https://saglik.gov.ct.tr/Haberler/DUYURULAR/ArtMID/32470/ArticleID/123979/SAĞLIKBAKANLIĞI-214NEMLI-A199IKLAMA. [Accessed: 04-Apr-2020].

[9] Turkish Republic of Northern Cyprus Ministry of Health, "Ministry of Health Description," 
2020. [Online]. Available:

https://saglik.gov.ct.tr/Haberler/DUYURULAR/ArtMID/32470/ArticleID/124007/Sağlık-

Bakanlı̆̆ı-A231ıklama. [Accessed: 04-Apr-2020].

[10] Turkish Republic of Northern Cyprus Ministry of Health, "The number of cases increased to 6 in the TRNC!," 2020. [Online]. Available:

https://saglik.gov.ct.tr/Haberler/DUYURULAR/ArtMID/32470/ArticleID/124245/KKTC'devaka-sayısı-6'ya-231ıktı. [Accessed: 04-Apr-2020].

[11] Turkish Republic of Northern Cyprus Ministry of Health, "Ministry of Health Statement Number of Cases increased to 20," 2020. [Online]. Available:

https://saglik.gov.ct.tr/Haberler/DUYURULAR/ArtMID/32470/ArticleID/124484/Sağlık-

Bakanlığı-A231ıklama. [Accessed: 04-Apr-2020].

[12] Turkish Republic of Northern Cyprus Ministry of Health, "Important Notice from the TRNC Ministry of Health," 2020. [Online]. Available:

https://saglik.gov.ct.tr/Haberler/DUYURULAR/ArtMID/32470/ArticleID/124273/Sağlık-

Bakanlığı'ndan-214nemli-Duyuru-Important-Notice-from-the-TRNC-Ministry-of-Health.

[Accessed: 04-Apr-2020].

[13] Turkish Republic of Northern Cyprus Ministry of Health, "Minister Pilli: 'With the statement of WHO, we immediately started preparations for a possible Corona virus outbreak,"' 2020. [Online]. Available:

https://saglik.gov.ct.tr/Haberler/DUYURULAR/ArtMID/32470/ArticleID/123618/Bakan-PilliDS214'n252n-a231ıklaması-ile-birlikte-olası160Korona-vir252s-salgınına-y246nelikhazırlıklara160hemen-başladık. [Accessed: 04-Apr-2020].

[14] Turkish Republic of Northern Cyprus Ministry of Health, "Council of Ministers decisions on Corona Virus," 2020. [Online]. Available: 
https://saglik.gov.ct.tr/Haberler/DUYURULAR/ArtMID/32470/ArticleID/124142/KoronaVir252s-ile-ilgili-Bakanlar-Kurulu-kararları. [Accessed: 04-Apr-2020].

[15] S. Zhao et al., "Preliminary estimation of the basic reproduction number of novel coronavirus (2019-nCoV) in China, from 2019 to 2020: A data-driven analysis in the early phase of the outbreak," Int. J. Infect. Dis., vol. 92, pp. 214-217, Mar. 2020.

[16] C. Yang and J. Wang, "A mathematical model for the novel coronavirus epidemic in Wuhan, China," 2019.

[17] U. T. Mustapha et.al., Modelling the transmission dynamics of the novel coronavirus disease (COVID-19), 2020 (submitted)

[18] Northern Cyprus Presidential Crisis Center, "Northern Cyprus Presidential Crisis Center," 2020. [Online]. Available: https://www.facebook.com/kktcbbiletisimbaskanligi/?ref=br_rs. [Accessed: 03-May-2020].

[19] TRNC State Planning Organization, “TRNC State planning Organization - Main site," 2020. [Online]. Available: http://www.devplan.org/. [Accessed: 04-Apr-2020]. 
Figures

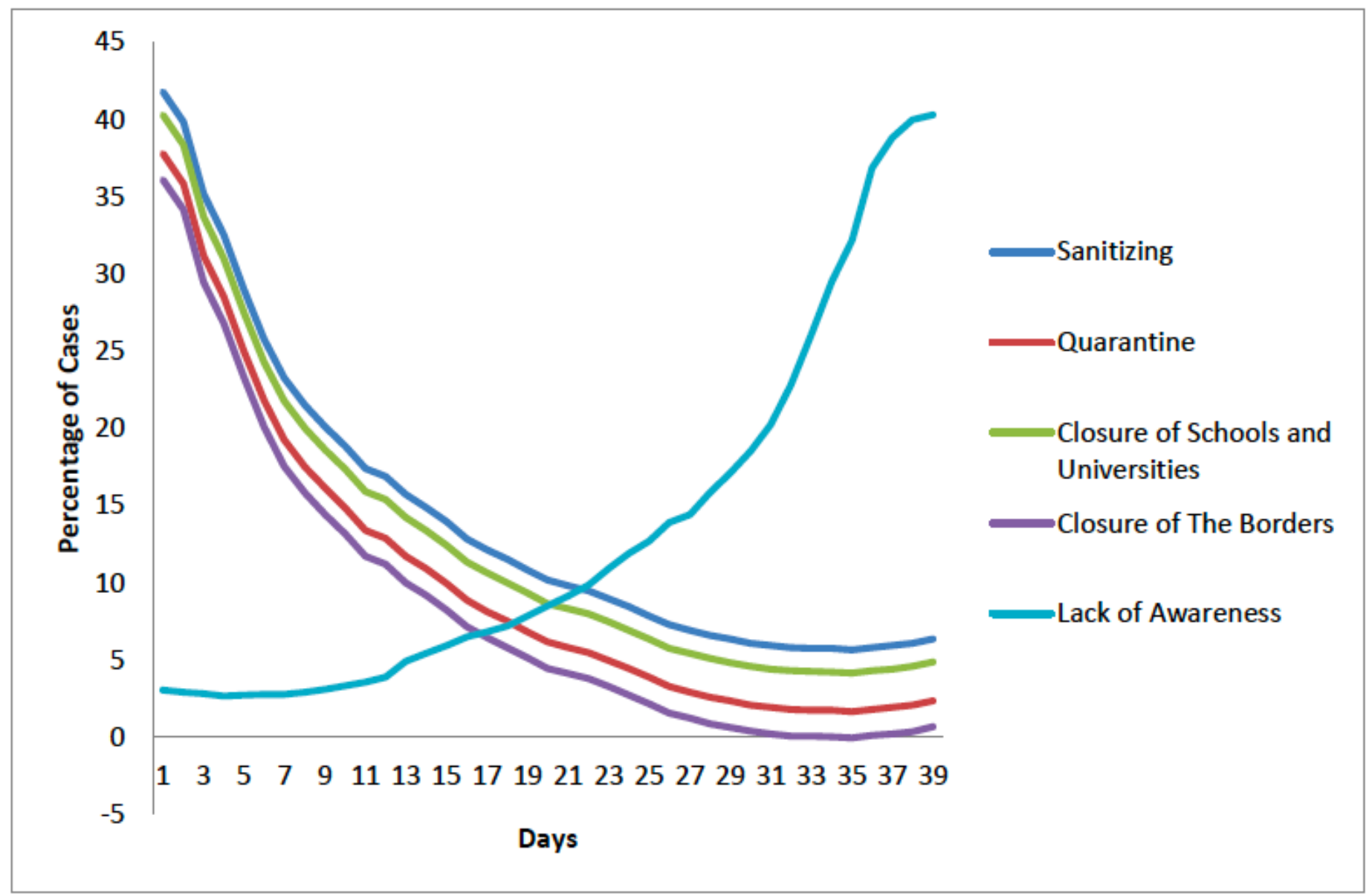

Figure 1

Most effective methods to prevent coronavirus epidemic 


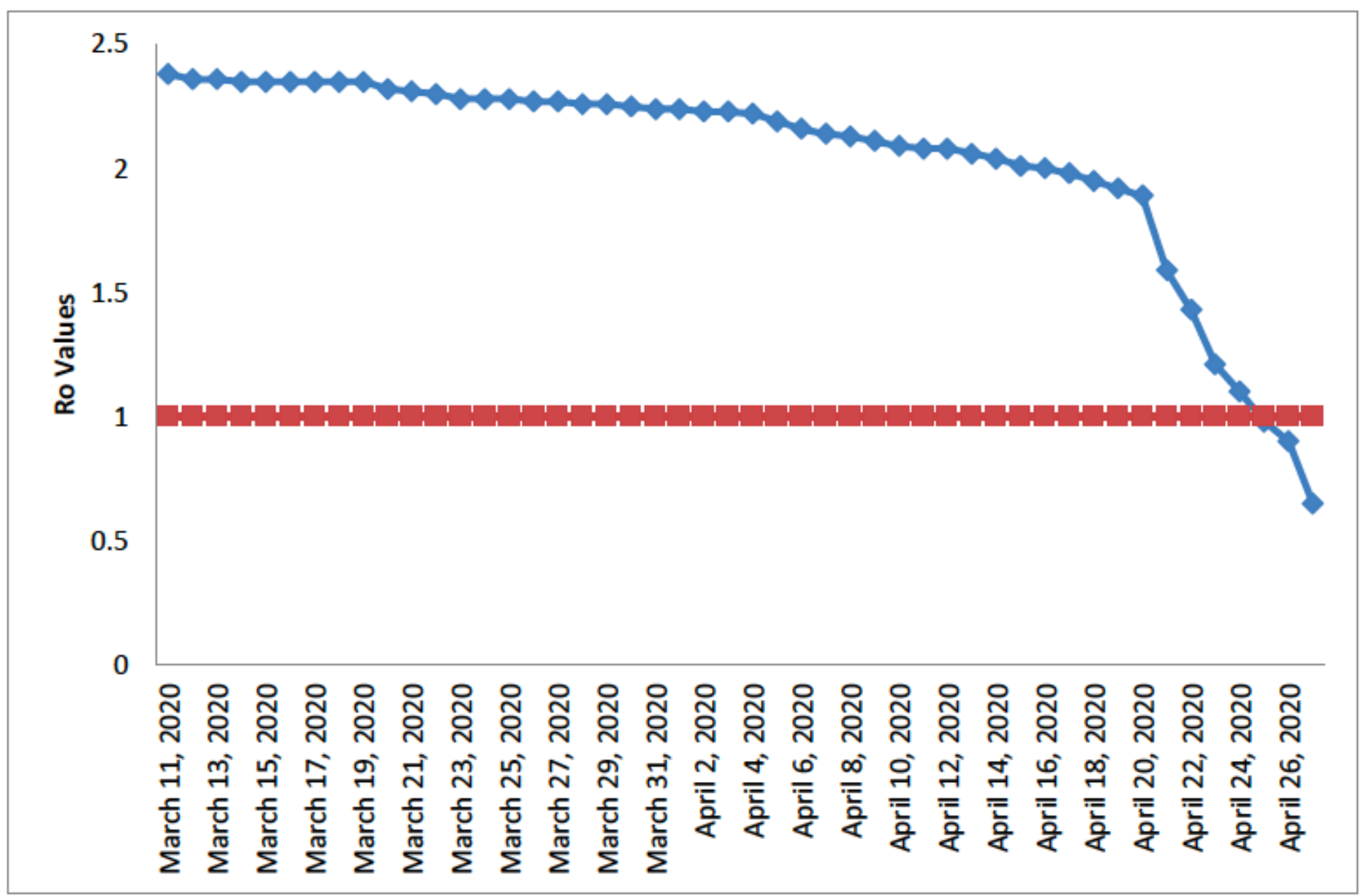

Figure 2

Northern Cyprus $\mathbb{}$ Q pattern for SARS-CoV-2 outbreak 


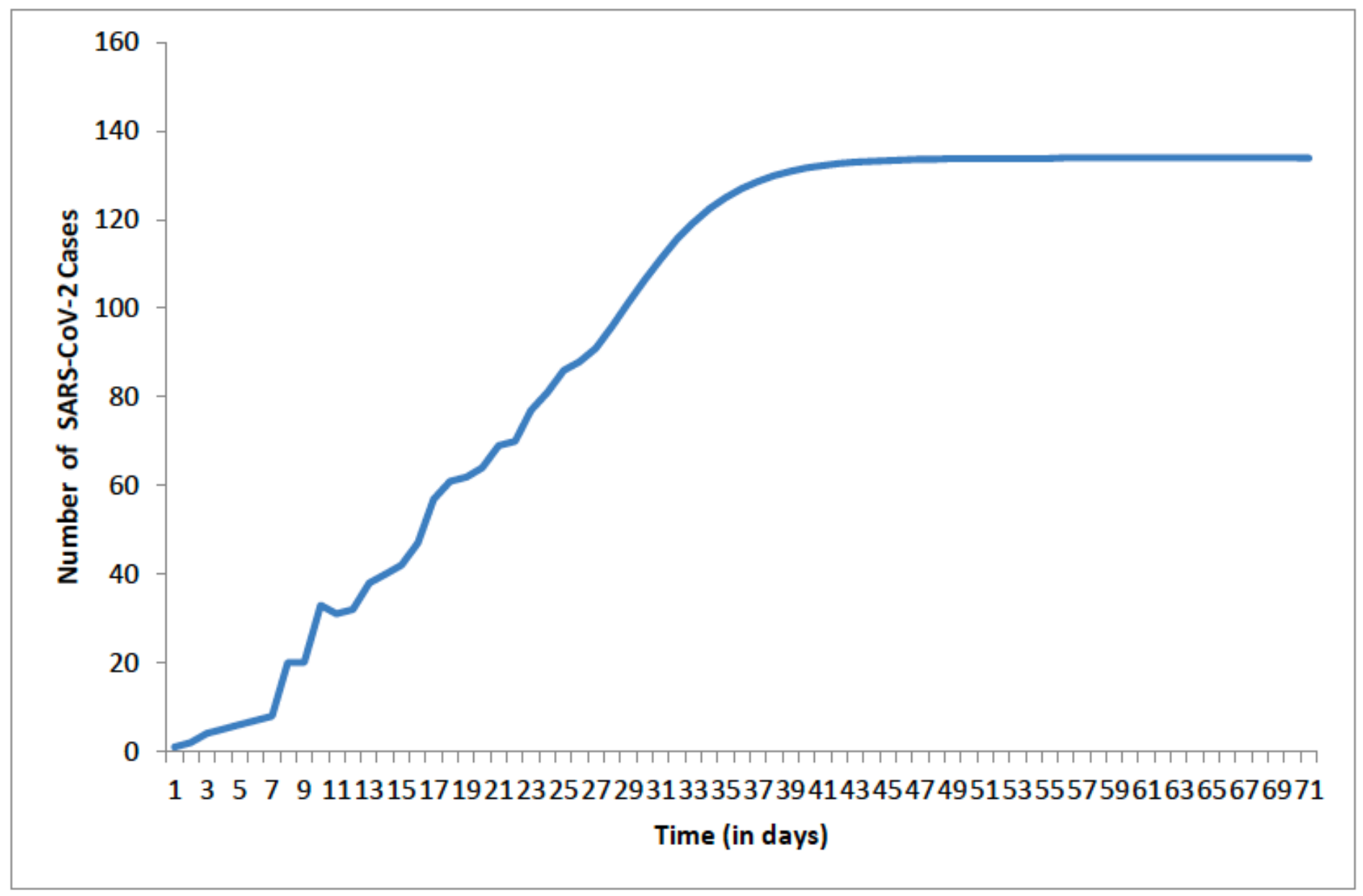

Figure 3

Northern Cyprus SEIR Model Simulation 